\title{
PENGARUH KONSENTARASI CARBOXYMETHYL CELULOSE TERHADAP KUALITAS ES KRIM UBI JALAR (Ipomea batatas L.)
}

\author{
Effect on Quality Concentrations Carboxymethyl Celulose Ice Cream \\ Purple Sweet Potatoes (Ipomea batatas L.)
}

\section{Meitycorfrida Mailoa*, Siti Rodiyah, dan Syane Palijama}

\author{
Jurusan Teknologi Hasil Pertanian Fakultas Pertanian Universitas Pattimura \\ Jl. Ir. M. Putuhena Kampus Poka Ambon 97233. \\ *Penulis Korespondensi: meitymailoa@gmail.com
}

\begin{abstract}
Modern food processing technology has resulted in the creations of a new processed purple sweet potato product, one of which is the purple sweet potato ice cream. Ice cream is a frozen food product that are usually consumed as a desert, with main ingredients such as fat, nonfat dry material or nonfat solids, sweeteners, stabilizers, and emulsifiers (CMC). This research was aimed to determine the optimal CMC emulsifier concentration in making sweet potato ice cream. The experimental design used was Completely Randomized Design with four treatments, namely A1 level (control), A2 (0.1\% CMC), A3 (0.3\% CMC), and A4 $(0.5 \% \mathrm{CMC})$. The results of this study indicate $\mathrm{CMC}$ concentration of $0.5 \%$ resulting in ice cream with a good quality, total sugar of $28.1 \%$, fat of $5.67 \%$, protein of $5.51 \%$, total solids of $37.51 \%$ and water content of $62.47 \%$. Organoleptic test results showed that with the CMC concentrations of $0.5 \%$, the panelists gave texture attribute values of 3.5 and the degree of preference of $3: 28$. The purple sweet potato ice cream with $\mathrm{CMC}$ concentration of 0.5 percent had a good quality because it fitted with ice cream quality terms according to the SII.
\end{abstract}

Keywords: carboxymethyl cellulose, ice cream, purple sweet potato

\begin{abstract}
ABSTRAK
Teknologi pengolahan pangan modern telah menghasilkan kreasi baru olahan ubi jalar ungu, salah satunya adalah es krim ubi jalar ungu. Es krim adalah produk pangan beku yang biasa dikonsumsi sebagai makanan selingan dengan bahan-bahan utama dalam pembuatannya seperti lemak, bahan kering tanpa lemak atau padatan bukan lemak, bahan pemanis, bahan penstabil, dan bahan pengemulsi. Penelitan ini bertujuan untuk mengetahui pengaruh konsentrasi bahan penstabil $(\mathrm{CMC})$ terhadap es krim ubi jalar ungu. Rancangan yang digunakan adalah Rancangan Acak Lengkap dengan empat taraf perlakuan yaitu A1 (kontrol), A2 (CMC 0,1\%), A3 (CMC 0,3\%), dan A4 (CMC 0,5\%). Hasil Penelitian ini menunjukan konsentrasi CMC 0,5\% menghasilkan es krim dengan kualitas baik, total gula $28,1 \%$, lemak $5,67 \%$, protein $5,51 \%$, total padatan $37,51 \%$ dan kadar air 62,47\%, Hasil uji organoleptik menunjukan konsentrasi CMC 0,5\% lebih disukai panelis dengan nilai atribut untuk tekstur 3,5, dan tingkat kesukaan 3,28, Es krim ubi jalar ungu dengan konsentrasi CMC 0,5\% memiliki kualitas baik karena sesuai dengan syarat mutu es krim menurut SII.
\end{abstract}

Kata kunci: carboximethyl cellulose, es krim, ubi jalar ungu

\section{PENDAHULUAN}

Tanaman ubi jalar (Ipomea batatas) berasal dari Amerika bagian Tengah dan pada sekitar tahun 1960-an ubi jalar telah menyebar dan ditanam di hampir seluruh wilayah Indonesia (Rukmana, 2001). Karakteristik umbi ubi jalar atau sweet potato adalah warna kulit antara jingga muda, 
jingga sampai cokelat muda, warna daging umbi jingga muda, jingga sampai kuning, dan rasa umbi manis, manis agak berair, manis berair sampai manis enak tergantung pada varietasnya. Beberapa varietas ubi jalar adalah seperti Daya, Prambanan, Borobudur, Mendut, dan Kalasan.

Berat kering umbi adalah $16-40 \%$ berat basah. Potensi besar ubi jalar terutama terletak pada kandungan karbohidrat, dimana sebanyak $75-90 \%$ berat kering umbi merupakan gabungan dari pati, gula, dan serat seperti selulosa, hemiselulosa, dan pektin (Hartoyo, 2004). Karbohidrat di dalam umbi ini telah banyak diolah lebih lanjut. Teknik olahan tradisional yang sudah banyak diterapkan di masyarakat dalam bentuk beberapa jajanan lokal, seperti kue apem, kue mangkok, dan pilus dari ubi jalar, termasuk juga keripik ubi jalar. Teknologi pengolahan pangan modern juga telah banyak berperan menghasilkan kreasi baru olahan ubi jalar, dengan bentuk yang paling banyak berupa jajanan atau makanan ringan (snack food). Dalam pembuatan makanan ini, ubi jalar dapat berperan sebagai bahan utama atau bahan pensubtitusi. Salah satu jenis makanan yang memanfaatkan umbi ubi jalar sebagai bahan bakunya adalah es krim ubi jalar. Penggunaan ubi jalar dalam pembuatan es krim selain sebagai bahan pengisi dan substitusi juga untuk meningkatkan cita rasa dan sebagai pewarna alami.

Es krim merupakan salah satu jenis makanan berbentuk beku dengan tekstur yang lembut dan memiliki gizi tinggi serta merupakan makanan yang digemari oleh berbagai golongan masyarakat. Susu merupakan bahan baku pembuatan es krim yang mengandung lemak berfungsi untuk menghaluskan tekstur, memberi cita rasa, serta memperindah penampakan. Bila kandungan lemak susu terlalu rendah, akan membuat es lebih besar dan teksturnya kasar serta terasa lebih dingin. Zat penstabil dapat menutupi sifat-sifat buruk yang diakibatkan kurangnya lemak susu dan memberi rasa lengket. Zat penstabil berfungsi untuk emulsi, yaitu membentuk selaput yang berukuran mikro untuk mengikat molekul lemak, air dan udara. Dengan demikian air tidak akan mengkristal dan lemak tidak akan mengeras. Zat penstabil juga bersifat mengentalkan adonan, sehingga selaput-selaput tadi bisa stabil. Zat penstabil atau stabilizer yang sering ditambahkan antara lain gelatin, gum arab, karagenan dan CMC. Dalam penelitian ini Penulis menggunakan $\mathrm{CMC}$ sebagai bahan penstabil.

Carboxy methyl cellulose (CMC) adalah salah satu jenis hidrokoloid atau bahan pengental yang sering digunakan dalam industri makanan. CMC merupakan turunan dari selulosa alami yang berfungsi untuk meningkatkan rasa di mulut (mouthfeel) dan memberi tekstur yang lebih baik. Bahan penstabil digunakan untuk mencegah pembentukan kristal es yang kasar, membentuk tekstur yang lembut, menghasilkan produk yang seragam, memberikan daya tahan yang baik terhadap proses pencairan, tidak berpengaruh terhadap titik beku namun cenderung membatasi pengembangan adonan. (Arbuckle, 1986). Berdasarkan uraian penjelasan ini maka penulis tertarik untuk melakukan suatu penelitian tentang Pengaruh Konsentrasi Carboxy Methyl Cellulose Terhadap kualitas Es Krim Ubi Jalar Ungu.

\section{METODE PENELITIAN}

\section{Bahan}

Bahan yang digunakan dalam penelitian adalah bubur ubi Jalar ungu, susu bubuk skim, susu bubuk full krim, gula pasir, CMC, telur, dan air.

\section{Pembuatan Es Krim}

Proses pembuatan es krim yang dilakukan dalam penelitian adalah sebagai berikut : Umbi dicuci, dikukus, lalu dikupas, kemudian ihaluskan. Kuning telur dikocok sampai mengembang. Bahanbahan kering dimasukkan ke dalam air hangat sambil diaduk. Campuran dipanaskan, sambil kuning telur, putih telur, dan CMC dimasukkan dan terus diaduk. Dipasteurisasi pada suhu $80-85^{\circ} \mathrm{C}$ selama 25 detik. Adonan diangkat, didinginkan sampai suam-suam kuku, kemudian dihomogenisasi selama 15 menit. Adonan disimpan di dalam refrigerator selama 4 jam untuk proses aging. Dihomogenisasi ulang selama 15 menit. Adonan disimpan di dalam freezer sampai setengah beku lalu diagitasi selama 15 menit. Dikemas dalam wadah-wadah kemudian disimpan kembali ke dalam freezer.

\section{Pengamatan}

Uji kimia yaitu total gula, lemak, protein, total padatan, dan kadar air dan uji organoleptik meliputi rasa, tekstur dan tingkat kesukaan

\section{Analisis Data}

Data hasil penelitian diuji secara statistik 
dengan menggunakan analisis keragaman sesuai dengan rancangan yang digunakan. Beda antara rataan perlakuan di uji dengan uji beda nyata terkecil (BNT) pada taraf 5\%.

\section{HASIL DAN PEMBAHASAN}

\section{Total Gula}

Pada Gambar 1, terlihat bahwa perlakuan A4 dengan konsentrasi CMC 0,5\% menghasilkan total gula tertinggi yaitu $28,1 \%$ sedangkan total gula terendah dihasilkan oleh perlakuan A1 yaitu 26,1\%.

Hasil Uji Beda menunjukkan bahwa perlakuan kontrol (A1) berbeda nyata dengan CMC 0,3\% (A3) dan CMC 0,5\% (A4). Demikian pula perlakuan $\mathrm{CMC} 0,1 \%$ (A2) berbeda nyata dengan perlakuan CMC 0,3\% (A3), dan CMC 0,5\% (A4). Serta CMC 0,5\% (A4) berbeda nyata dengan CMC $0,3 \%$ (A3).

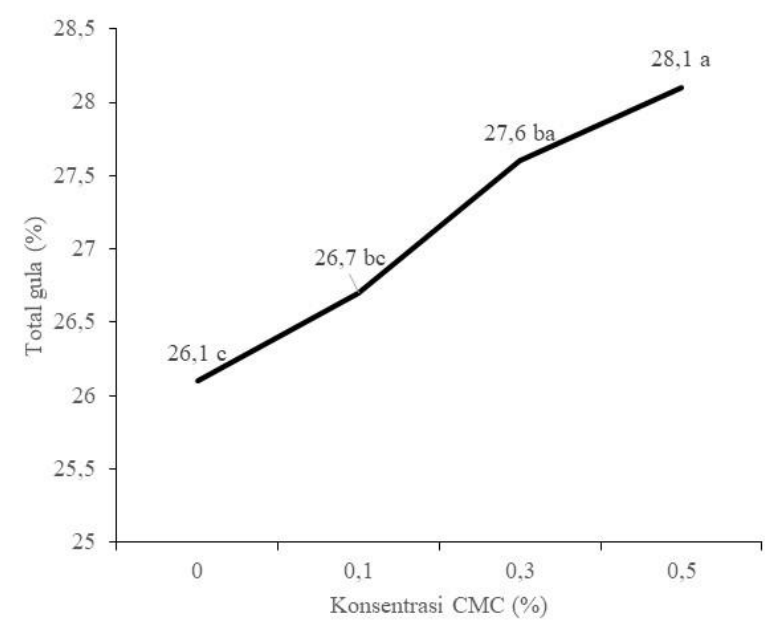

Gambar 1. Kurva Pengaruh Konsentrasi CMC terhadap Total Gula Es Krim Ubi Jalar

Tingginya total gula yang dihasilkan oleh perlakuan A4 yaitu sebesar 28,1\% disebabkan konsentrasi CMC yang ditambahkan terhitung sebagai gula total sehingga makin tinggi konsentrasi CMC yang ditambahkan, maka total gula yang terukur juga semakin tinggi. Kecenderungan total gula meningkat dengan meningkatnya konsentrasi CMC. Hal ini karena selulosa merupakan homopolisakarida liniar yang berbobot molekular tinggi dengan satuan pengulang selobiosa (David, 1985).

CMC dalam pembuatan es krim dapat meningkatkan cita rasa dan total gula. Kandungan total gula yang terdapat pada es krim ubi jalar membuktikan bahwa adanya kompleksitas antara gula pereduksi (glikon) dan bukan gula pereduksi (aglikon). Hal ini disebabkan CMC berperan sebagai stabilizer, pengikat air, serta mampu mengikat senyawa lain seperti gula (sukrosa), di mana sukrosa mengandung gula reduksi sebesar $1,24 \%$. sehingga dengan penambahan CMC kandungan total gula es krim akan meningkat.

\section{Kadar Lemak}

Pada Gambar 2, terlihat bahwa perlakuan A4 dengan konsentrasi CMC 0,5\% menghasilkan kadar lemak tertinggi yaitu 5,67\% sedangkan kadar lemak terendah dihasilkan oleh perlakuan A1 yaitu 3,84\%.

Hasil uji Beda nyata menunjukkan antara perlakuan CMC 0,5\% (A4) dan CMC 0,3\% (A3) tidak berbeda nyata, tapi keduanya berbeda nyata dengan kontrol (A1) dan CMC $0,1 \%$ (A2), sedangkan kontrol (A1) berbeda nyata dengan CMC 0,5\% (A4), dan perlakuan CMC 0,1\% (A2) berbeda nyata dengan CMC 0,3\% (A3).

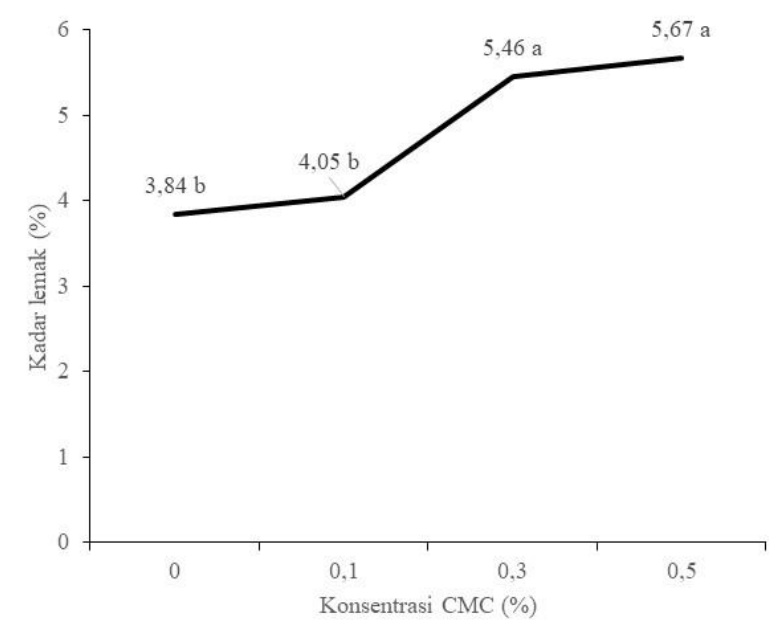

Gambar 2. Kurva Pengaruh Konsentrasi CMC terhadap Lemak Es Krim Ubi Jalar

Perlakuan A4 dengan konsentrasi CMC 0,5\% menghasilkan kadar lemak tertinggi yaitu 5,67\% sedangkan kadar lemak terendah dihasilkan oleh perlakuan A1 yaitu sebesar 3,84\%, hal ini karena semakin tinggi konsentrasi CMC yang ditambahkan maka kadar lemak yang dihasilkan semakin besar pula. Hal ini karena CMC memiliki sifat viskositas yang tinggi mampu mempengaruhi stabillitas emulsi lemak dalam air sehingga dengan penambahan CMC kadar lemak pada es krim terjaga kesimbangannya. sehingga semakin tinggi konsentrasi CMC yang ditambahkan maka akan meningkatkan kadar lemak es krim. 
Menurut Standar Industri Indonesia (SNI, 1995), lemak yang terkandung dalam es krim yaitu minimal 5\%, sedangkan es krim yang beredar di pasaran memiliki kadar lemak sebesar 6,52\%. Pada perlakuan Konsentrasi CMC mengandung lemak sebesar 5,62\% sehingga sudah sesuai dengan SNI.

\section{Kadar Protein}

Hasil uji beda menunjukkan bahwa perlakuan CMC 0,1\% (A2), CMC 0,3\% (A3), CMC 0,5\% (A4) tidak berbeda nyata sama lain, tapi berbeda nyata dengan perlakuan kontrol (A1). Pada Gambar 3 , terlihat bahwa perlakuan konsentrasi tertinggi dihasilkan oleh perlakuan A4 dengan kadar protein yaitu $5,51 \%$ sedangkan kadar protein terendah dihasilkan oleh perlakuan A1 yaitu 4,57\%. Hal ini disebabkan pada perlakuan A1 tidak menggunakan CMC, sedangkan perlakuan yang lainnya menggunakan CMC. Menurut Fardiaz (1992), CMC dapat mencegah pengendapan protein pada titik isoelektrik dan meningkatkan kekentalan, hal ini disebabkan bergabungnya gugus karboksil CMC dengan gugus muatan positif dari protein susu.

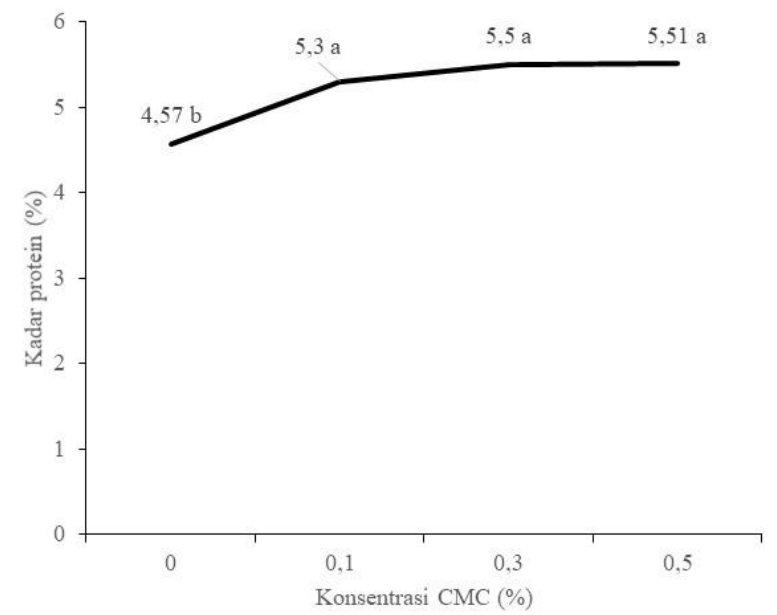

Gambar 3. Kurva Pengaruh Konsentrasi CMC terhadap Protein Es Krim Ubi Jalar

Keunggulan es krim didukung oleh bahan baku utamanya, yaitu susu tanpa lemak dan lemak susu. Susu disebut sebagai makanan yang hampir sempurna karena kandungan zat gizi yang lengkap. Unsur protein dalam pembuatan es krim berfungsi untuk menstabilkan emulsi lemak, menambah citarasa, membantu pembuihan, meningkatkan dan menstabilkan daya ikat air yang berpengaruh pada kekentalan dan tekstur es krim yang lembut, juga dapat meningkatkan nilai over run es krim.
Susu termasuk dalam golongan pangan fungsional. Pangan fungsional merupakan pangan yang memiliki efek kesehatan lain di samping efek zat gizinya. Susu mengandung beberapa komponen bioaktif yang memiliki efek kesehatan yang signifikan. Komponen bioaktif susu di antaranya adalah protein susu, laktosa, asam-asam lemak dan mineral, terutama kalsium. Hal ini menyebabkan produk-produk turunan susu juga masih memiliki efek fungsional, termasuk es krim. Sebagian besar komponen dalam susu telah diketahui fungsinya secara biologis bagi tubuh. Komponen yang telah diketahui fungsinya adalah protein terutama dari bagian whey, termasuk di dalamnya alfalaktalbumin, betalaktoglobulin, imntiunoglobulin, laktoferin, dan glikomakropeptida.

\section{Total Padatan}

Pada Gambar 4, terlihat bahwa perlakuan A4 dengan konsentrasi CMC 0,5\% menghasilkan total padatan tertinggi yaitu $37,51 \%$ sedangkan total padatan terendah dihasilkan oleh perlakuan A1 yaitu $35,02 \%$.

Hasil uji beda nyata menunjukkan bahwa perlakuan kontrol (A1) berbeda nyata dengan perlakuan CMC 0,1\% (A2), CMC 0,3\% (A3), dan CMC $0,5 \%$ (A4). Sedangkan A2 dan A3 tidak berbeda nyata, dan CMC $0,5 \%$ (A4) berbeda nyata dengan semua perlakuan.

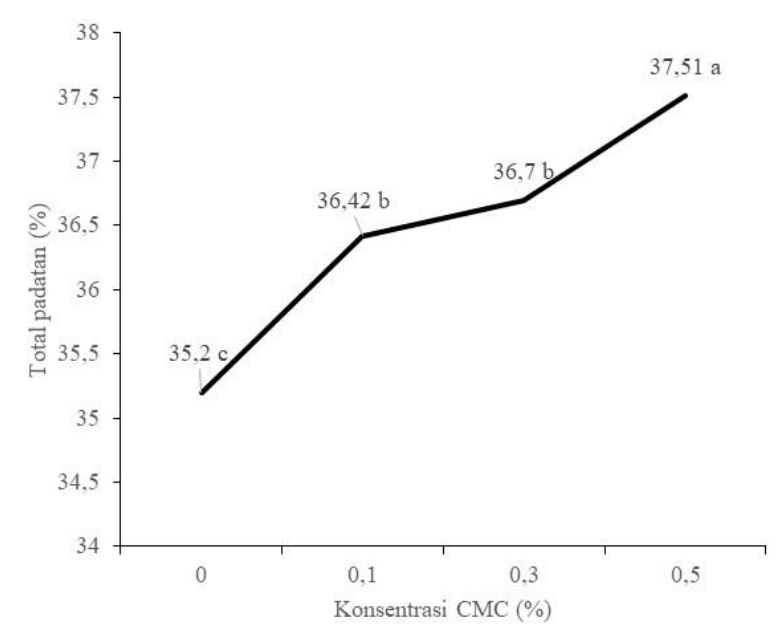

Gambar 4. Kurva Pengaruh Konsentrasi CMC terhadap Total Padatan Es Krim Ubi Jalar

Perlakuan konsentrasi CMC 0,5\% memiliki kandungan total padatan tertinggi yaitu $37,51 \%$ karena CMC juga mampu menjaga suspensi karena muatan negatifnya yang memungkinkan membentuk pembungkus bagi partikel yang 
tersuspensi sehingga larutan CMC pada air akan menghasilkan pembentukan gumpalan atau endapan ikatan menyilang yang tidak larut.

Dengan penambahan konsentrasi CMC akan menambah jumlah padatan yang terlarut dan berpengaruh pada total padatan terlarut dalam es krim. Total padatan es krim juga dipengaruhi oleh komponen padatan yang terlarut yaitu sukrosa dan susu skim.

\section{Kadar Air}

Pada Gambar 5, terlihat bahwa perlakuan A4 dengan konsentrasi CMC $0,5 \%$ menghasilkan kandungan air terendah yaitu $62,47 \%$ sedangkan kandungan air tertinggi dihasilkan oleh perlakuan A1 yaitu $64,97 \%$.

Hasil uji beda menunjukkan bahwa perlakuan kontrol (A1) berbeda nyata dengan perlakuan CMC $0,1 \%$ (A2), CMC 0,3\% (A3), dan CMC 0,5\% (A4). sedangkan $\mathrm{CMC} 0,3 \%$ (A3) tidak berbeda nyata dengan CMC 0,5\% (A4).

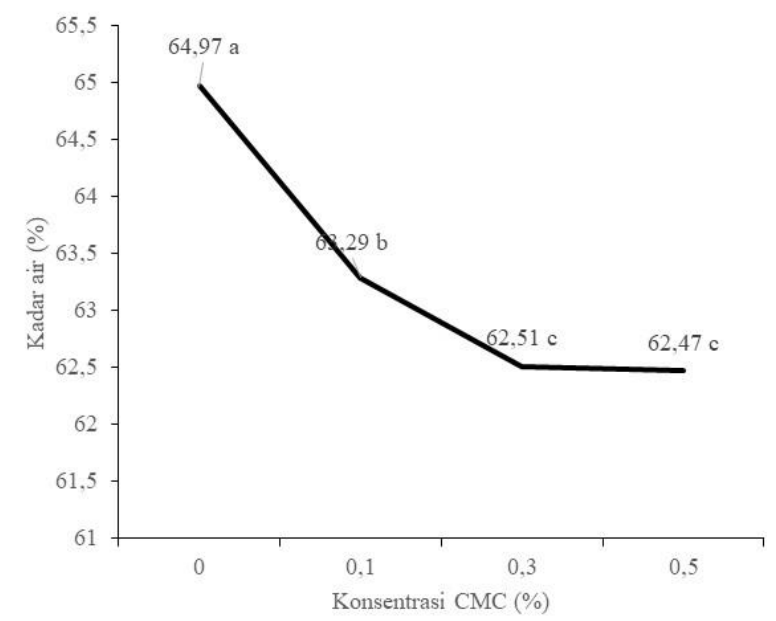

Gambar 5. Kurva Pengaruh Konsentrasi CMC terhadap Kadar Air Es Krim Ubi Jalar

Rendahnya kandungan air yang dihasilkan oleh perlakuan CMC 0,5\% disebabkan karena CMC mampu dalam mengikat air sehingga molekul air terperangkap dalam struktur gel yang terbentuk oleh CMC. Menurut Fardiaz, (1992), kandungan air terendah dihasilkan oleh perlakuan CMC 0,5\% karena disebabkan oleh kemampuan CMC dalam mengikat air sehingga molekul air terperangkap dalam struktur gel yang yang terbentuk, air yang sebelumnya berada diluar granula dan bebas bergerak dengan adanya CMC, maka tidak dapat bergerak bebas lagi karena terserap dan terikat pada butiran-butiran CMC sehingga keadaan larutan menjadi lebih mantap. Jadi semakin tinggi konsentrasi CMC yang ditambahkan maka kadar airnya semakin rendah.

\section{Rasa}

Nilai rata - rata pada uji rasa panelis terhadap rasa es krim ubi jalar di sajikan pada Gambar 6, yang menunjukkan bahwa perlakuan A1 (kontrol), memiliki nilai tertinggi yaitu 2,6 di bandingkan perlakuan lainnya, sedangkan nilai rata - rata terkecil dihasilkan perlakuan A4 dengan konsentrasi CMC $(0,5 \%)$ dengan nilai 2,1 . Hal ini menunjukkan bahwa semakin tinggi penambahan $\mathrm{CMC}$, rasa ubi jalarnya semakin berkurang.

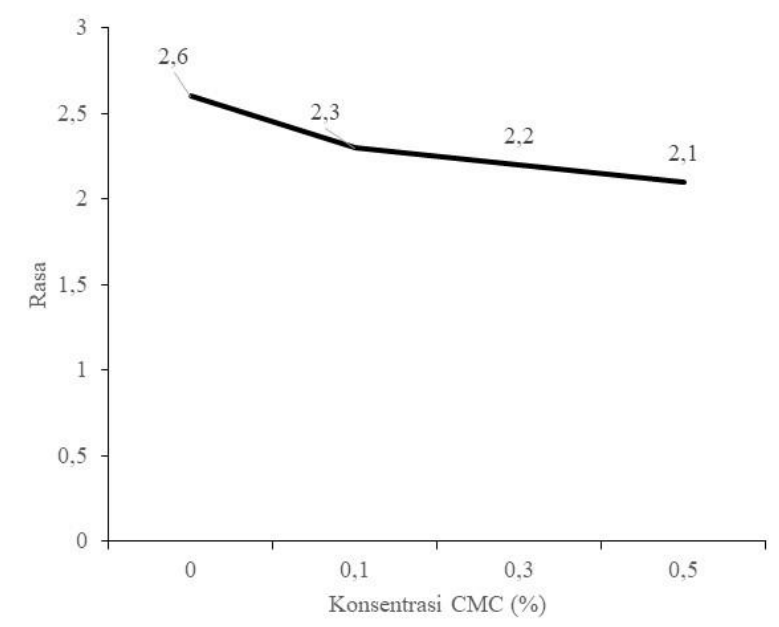

Gambar 6. Kurva Pengaruh Konsentrasi CMC terhadap Rasa Es Krim Ubi Jalar

Rasa sangat mempengaruhi kesukaan konsumen terhadap es krim, bahkan dapat dikatakan sebagai faktor penentu utama. Saat ini, rasa es krim dipasaran sudah sangat beragam sehingga diperlukan kejelian dan kreativitas untuk memadupadankan rasa yang menjadi kegemaran konsumen. Menurut Padaga \& Sawitri (2005), rasa es krim juga dipengaruhi oleh beberapa hal seperti bahan penstabil, penggunaan bahan - bahan (gula, susu, dan telur) yang ditambahkan dalam adonan dan perubahan tekstur yang dapat mengubah citarasa es krim, sehingga semakin tinggi penambahan konsentasi CMC yang diberikan maka rasa khas ubi jalar berkurang, dan menyebabkan penurunan nilai rata - rata.

\section{Tekstur}

Nilai rata - rata uji tekstur es krim ubi jalar dari panelis disajikan pada Gambar 7, yang 
menunjukkan bahwa perlakuan A4 dengan konsentrasi CMC $(0,5 \%)$, memiliki nilai tertinggi yaitu 3,8 , di bandingkan perlakuan lainnya, sedangkan nilai rata - rata terkecil dihasilkan pada perlakuan A1 (kontrol) dengan nilai 2,1. Hal ini disebabkan semakin tinggi konsentrasi CMC yang ditambahkan tekstur es krim semakin lembut. Tekstur es krim semakin lembut karena salah satu fungsi CMC dalam adonan untuk memperbaiki tekstur dan kristal laktosa yang terbentuk akan lebih halus dan mencegah retrogradasi (Winarno, 2004).

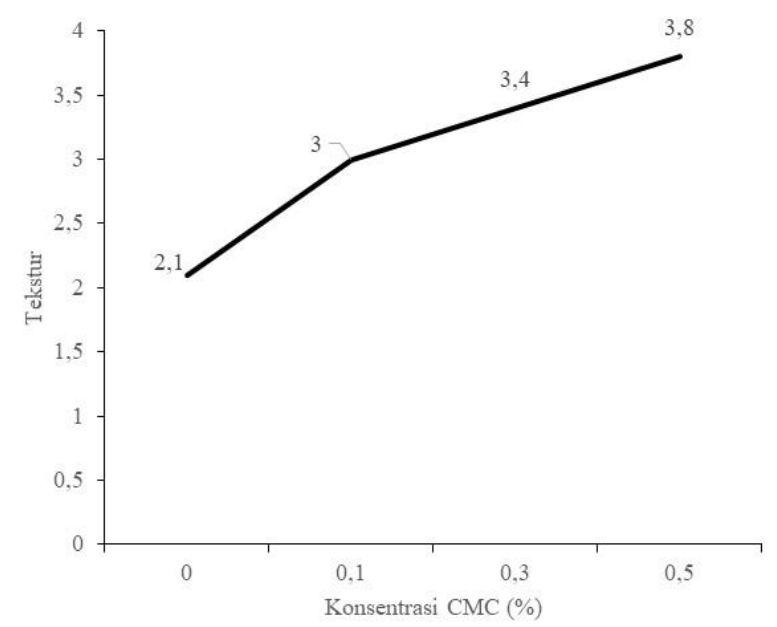

Gambar 7. Kurva Pengaruh Konsentrasi CMC terhadap Tekstur Es Krim Ubi Jalar

Tekstur es krim dipengaruhi oleh ukuran dari kristal es, globula lemak, gelembung udara, dan kristal laktosa (Suprayitno et al., 2001), sedangkan menurut Padaga \& Sawitri (2005), tekstur lembut es krim sangat dipengaruhi oleh komposisi bahan penstabil, cara mengolah, dan kondisi penyimpanan. Tekstur es krim yang baik adalah halus atau lembut (smooth), tidak keras, dan tampak mengkilap, sementara tekstur yang buruk adalah greasy (terasa ada gumpalan lemak), grainy (terasa seperti tepung), flaky/snowy (terasa ada serpihan es), lumpy/gelatin (seperti jelly), dan sandy (berpasir) (Suprayitno et al., 2001). Sejalan juga dengan pendapat Syahputra (2008) dalam Darma et al. (2013) bahwa lemak dapat meningkatkan kehalusan es krim, karena lemak dapat memperkecil pembentukan kristal es pada saat pembekuan. Pada penelitian ini dengan penambahan CMC maka lemak semakin tinggi sehingga mempengaruhi kehalusan es krim.

CMC dalam produk pangan seperti es krim berperan untuk memperbaiki tekstur karena bahan penstabil berfungsi menjaga air dalam es krim agar tidak membeku benar dan mengurangi kristalisasi es (Hartatie, 2011). Molekul-molekul air terperangkap dalam struktur gel yang dibentuk oleh CMC dan meningkatkan viskositas es krim, menstabilkan emulsi sehingga pembentukan kristal es yang besar dapat dicegah dan tekstur yang dihasilkan lebih halus (Potter and Norman, 1986 dalam Sumardikan 2007).

\section{Tingkat Kesukaan}

Nilai rata-rata uji kesukan panelis terhadap tingkat kesukaan es krim ubi jalar di sajikan pada Gambar 8, yang menunjukkan bahwa perlakuan A4 dengan konsentrasi CMC $(0,5 \%)$, memiliki nilai tertinggi yaitu 3,8 , di bandingkan perlakuan lainnya. sedangkan nilai rata-rata terkecil dihasilkan perlakuan A1 (kontrol) dengan nilai 2,5.

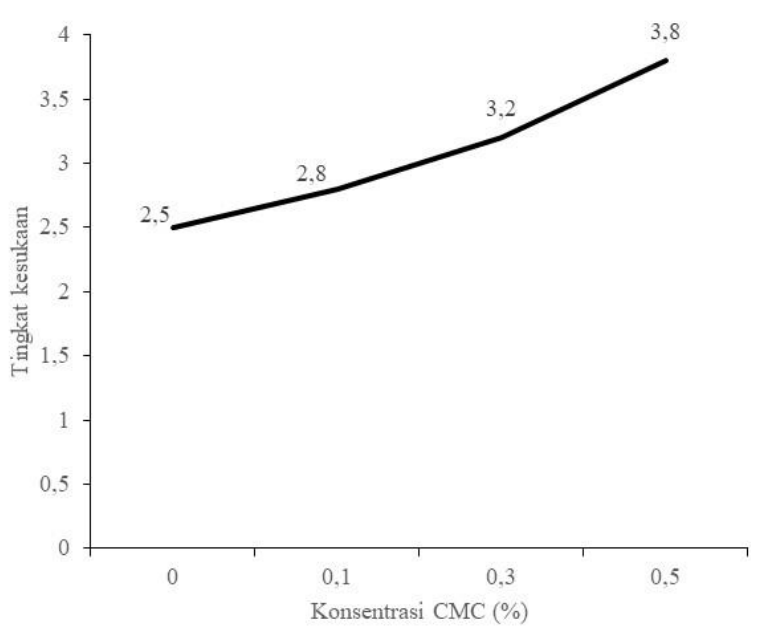

Gambar 8. Kurva Pengaruh Konsentrasi CMC terhadap Tingkat Kesukaan Es Krim Ubi Jalar

Data pada Gambar 8, menunjukkan bahwa panelis lebih menyukai es krim dengan konsentrasi CMC 0,5\% karena perlakuan tersebut memiliki rasa dan tekstur yang sangat lembut, sehingga makin disukai panelis. Hal ini karena sebagai pengemulsi CMC sangat baik digunakan untuk memperbaiki kenampakan tekstur dari produk berkadar gula tinggi. Sebagai pengental, CMC mampu mengikat air sehingga molekul-molekul air terperangkap dalam struktur gel yang dibentuk oleh CMC (Fardiaz, 1992).

Menurut Belitz \& Grosh, (1986) dalam Sumardikan (2007), CMC merupakan bahan penstabil yang memiliki daya ikat yang kuat dan berperan untuk meningkatkan kekentalan dan tekstur produk makanan, seperti produk es, jelli, dan salad. 


\section{KESIMPULAN}

1. Konsentrasi CMC memberikan pengaruh yang berbeda sangat nyata terhadap es krim ubi jalar ungu

2. Konsentrasi CMC 0,5\% menghasilkan es krim dengan kualitas baik, dengan kandungan total gula $28,1 \%$, kadar lemak $5,67 \%$, kadar protein $5,51 \%$, total padatan $37,51 \%$ dan kadar air $62,47 \%$.

3. Hasil uji organoleptik menunjukkan konsentrasi CMC 0,5\% lebih disukai panelis dengan nilai atribut untuk tekstur 3,8, tingkat kesukaan 3,8.

4. Es krim ubi jalar ungu dengan konsentrasi CMC 0,5\% memiliki kualitas baik karena sesuai dengan syarat mutu es krim menurut SII.

\section{DAFTAR PUSTAKA}

Arbuckle, W.S. 1977. Ice Cream. Third Edition. Avi Publishing Company, IncWest Port, Connecticut.

Darma, G.S., D. Puspitasari, dan E. Noerhartati. 2013. Pembuatan es krim jagung manis kajian jenis zat penstabil, konsentrasi non dairy creamserta aspek kelayakan finansial. Jurnal REKA Agroindustri 1: 45-55.
David, S.P. 1997. Prinsip-Prinsip Biokimia. Penerbit Erlangga. Jakarta.

Fardiaz, S. 1992. Mikrobiologi Pangan. PT. Gramedia Pustaka. Jakarta.

Hartatie, E.S. 2011. Kajian formulasi (bahan baku, bahan pemantap) dan metode pembuatan terhadap kualitas es krim. Jurnal Gamma 7: 20-26.

Hartoyo, T. 2004. Olahan dari Ubi Jalar. Trubus Agrisarana. Surabaya.

Padaga, M. dan M.E. Sawitri. 2005. Es Krim yang Sehat. Trubus Agrisarana, Surabaya.

Rukmana, H.R. 2001. Aneka Keripik Umbi. Penerbit Kanisius. Yogyakarta.

SNI 01-3713-1995. 1995. Es Krim. Badan Standarisasi Nasional. Jakarta.

Suprayitno, E., K. Ningsih, dan S. Rahayu. 2001. Pembuatan es krim dengan menggunakan stabilisator natrium alginat dari Sargassum sp. Jurnal Makanan Tradisional Indonesia 1: 23-27.

Sumardikan, H. 2007. Penggunaan Carboxymethyl Cellulose (CMC) Terhadap pH, Keasaman, Viskositas, Sineresis dan Mutu Organoleptik Yogurt Set. [Skripsi]. Teknologi Hasil Ternak. Fakultas Perternakan. Universitas Brawijaya. Malang.

Winarno, F.G. 2004. Kimia Pangan dan Gizi. Penerbit Gramedia Pustaka Utama. Jakarta. 